\title{
Effect of Land Configuration and Bio-organic on Exchangeable Cations and Exchangeable Sodium Percentage of Soil after Harvest of Chickpea (Cicer arietinum L.) Under Costal Salt Affected Soils
}

\author{
Vikas Vishnu ${ }^{1}$, V.P. Usadadia ${ }^{2}$, Anil Kumar Mawalia ${ }^{1}$ and M.M. Patel ${ }^{2}$ \\ ${ }^{1}$ Department of Agronomy, N.M. College of Agriculture, Navsari Agricultural University, \\ Navsari- 396450 (Gujarat), India \\ ${ }^{2}$ Soil and Water Management Research Unit, Navsari Agricultural University, \\ Navsari - 396450 (Gujarat), India \\ *Corresponding author
}

\begin{tabular}{|c|c|}
\hline & A B S T R A C T \\
\hline $\begin{array}{l}\text { Bio-organic, } \\
\text { Chickpea, Costal } \\
\text { salt affected soils, } \\
\text { Exchangeable } \\
\text { cations, ESP, Land } \\
\text { configuration. }\end{array}$ & \multirow{3}{*}{ 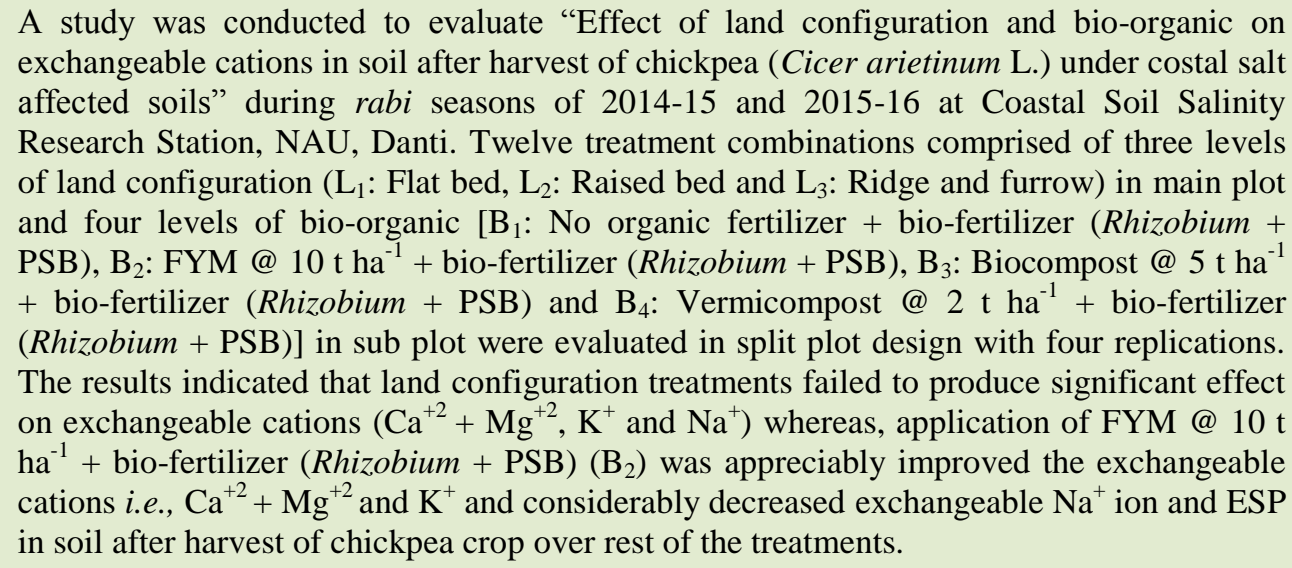 } \\
\hline Article Info & \\
\hline $\begin{array}{l}\text { Accepted: } \\
\text { 02 March } 2017 \\
\text { Available Online: } \\
10 \text { April } 2017\end{array}$ & \\
\hline
\end{tabular}

\section{Introduction}

In India, salt affected soils occupy about 9.38 million ha of cultivated land of which around 41 per cent is sodic i.e., 3.88 million ha and 5.5 million ha are saline soils (including coastal) (IAB, 2000). These occur from Jammu and Kashmir (Ladakh region) in North to Kanyakumari in South and Andaman and Nicobar Islands in the East to Gujarat in the West. In Gujarat, an area of 1.69 million ha is affected by either salinity or sodicity or both (Minhas et al., 1998). On account of account of higher proportion of exchangeable $\mathrm{Na}^{+}$on exchange complex, the high clay containing soils of south Gujarat exhibit poor physical conditions viz., low permeability, crusting and hardening of surface soil upon drying and cracking. As a result of this, restricted air and water movement in soil and poor root growth is observed. The extent of adverse effect of soil sodicity is dependent upon the texture of soil (Velayutham and Bhattacharya, 2000). Expanding problems of 
soil salinity and water logging have become serious issues of concern as they affect productivity and threaten the very sustainability of agriculture under coastal salt affected soils, where rice is predominant during kharif. High substrate salinity is a major limiting factor for crop production in coastal habitats.

Chickpea (Cicer arietinum L.) is third most extensively growing grain legume. Besides being a valuable source of energy and protein to Indian diet, the crop also plays an important role in the maintenance of soil fertility. As with many other pulses, chickpea is a salt-sensitive crop and yield is seriously reduced particularly by chloride salinity as well as carbonate and bicarbonate of sodium. High salinity decreases substrate water potential and thus restricts water and nutrient uptake by the roots, high salinity may also cause ionic imbalance and toxicity in plants. Seed germination is delayed and reduced, seedling emergence and vegetative plant growth are suppressed under saline conditions (Yadav et al., 1989). So far, there is a need to find out scientific approaches for sustainable and profitable production of chickpea on salt affected soils to meet the increasing demand.

\section{Materials and Methods}

The study was conducted during rabi 2014-15 and 2015-16 at Coastal Soil Salinity Research

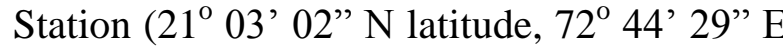
longitude, three metre above mean sea level), Navsari Agricultural University, Danti. The experiment comprising of twelve treatment combinations comprised of three levels of land configuration $\left(\mathrm{L}_{1}\right.$ : Flat bed, $\mathrm{L}_{2}$ : Raised bed and $\mathrm{L}_{3}$ : Ridge and furrow) in main plot and four levels of bio-organic $\left[\mathrm{B}_{1}\right.$ : No organic fertilizer + bio-fertilizer (Rhizobium + PSB), $\mathrm{B}_{2}$ : FYM @ $10 \mathrm{t} \mathrm{ha}^{-1}+$ bio-fertilizer (Rhizobium + PSB), B 3 : Biocompost @ $5 \mathrm{t} \mathrm{ha}^{-1}$ + bio-fertilizer (Rhizobium + PSB) and $\mathrm{B}_{4}$ : Vermicompost @ $2 \mathrm{t} \mathrm{ha}^{-1}+$ bio-fertilizer
(Rhizobium + PSB)] in sub plot were evaluated in split plot design with four replications. Before the commencement of the experiment, composite soil sample $(0-15 \mathrm{~cm}$ depth) was collected and covering entire area of experimental field before sowing. The soil sample was air-dried, grind and passed through $2 \mathrm{~mm}$ sieve and analyzed for different physico-chemical properties (Table 1) and same method also used for analysis of exchangeable cations and ESP after harvest of crop. As per the soil properties during the cropping seasons of 2014-15 and 2015-16, the soil of the experimental field was clayey in texture, medium in OC and highly salinesodic, so this type of soil moderately suitable for growing of chickpea crop. Required quantity of organic manure i.e., FYM, biocompost and vermicompost were worked out for gross plot area as per treatment. FYM, biocompost and vermicompost were applied in respective treatments after preparing beds, mix it by using kudali and then ridge and furrow and raised beds were prepared. FYM, biocompost and vermicompost @ 10, 5 and 2 $\mathrm{t} \mathrm{ha}{ }^{-1}$, respectively were applied in respective treatments just before sowing of crop and biofertilizer (Rhizobium + PSB) as seed treatment was applied as per treatment.

\section{Results and Discussion}

\section{Effect of land configuration}

Land configuration treatments did not cause significant variation on exchangeable cations $\left(\mathrm{Ca}^{+2}+\mathrm{Mg}^{+2}, \mathrm{~K}^{+}\right.$and $\left.\mathrm{Na}^{+}\right)$in soil after harvest of crop (Table 2) during both the years of study. Although, numerically increased exchangeable cations i.e., $\mathrm{Ca}^{+2}+\mathrm{Mg}^{+2}$ and $\mathrm{K}^{+}$ and decreased exchangeable $\mathrm{Na}^{+}$in soil after harvest of chickpea crop under ridge and furrow method $\left(\mathrm{L}_{3}\right)$. The value of exchangeable cations more might be due to more crop residues remain in soil which may increase organic matter in soil ultimately increased exchangeable cations i.e., $\mathrm{Ca}^{+2}+$ 
$\mathrm{Mg}^{+2}$ and $\mathrm{K}^{+}$and decreased exchangeable $\mathrm{Na}^{+}$ in soil by the displacement of $\mathrm{Ca}^{+2}$ and $\mathrm{Mg}^{+2}$ ions.

Exchangeable sodium percentage (Table 2) in soil after harvest of chickpea was not influenced statistically due to land configuration treatments during both the years. Looking to the results, reduction of ESP in soil was to the tune of 6.36 and 5.96 per cent during 2014-15 and 2015-16, respectively due to ridge and furrow sowing treatment than flat bed. The decrease in ESP may be attributed to displacement of $\mathrm{Na}^{+}$by $\mathrm{Ca}^{+2}$ and $\mathrm{Mg}^{+}$ions on exchangeable complex due to increased solubilization of $\mathrm{CaCO}_{3}$ by the carbonic acid produced as a result of the microbial decomposition/humification of organic matter. Higher root proliferation might have been another important cause as the $\mathrm{CO}_{2}$ exhaled by roots as a result formation of carbonic acid. These findings corroborate the results obtained by Rathod et al., (2004) in gatton panic under broad bed and furrow method.

\section{Effect of bio-organic}

The data further revealed that different treatments of bio-organic brought out significant influenced on exchangeable cations $\left(\mathrm{Ca}^{+2}+\mathrm{Mg}^{+2}, \mathrm{~K}^{+}\right.$and $\left.\mathrm{Na}^{+}\right)$in soil after harvest of chickpea during the crop growing seasons of 2014-15 and 2015-16. Significantly higher exchangeable cations i.e., $\mathrm{Ca}^{+2}+\mathrm{Mg}^{+2}$ with 48.7 and $49.4 \mathrm{cmol}\left(\mathrm{p}^{+}\right) \mathrm{kg}^{-1}$ and $\mathrm{K}^{+}$with 2.98 and $3.14 \mathrm{cmol}\left(\mathrm{p}^{+}\right) \mathrm{kg}^{-1}$ were recorded under treatment $\mathrm{B}_{2}$ [FYM @ $10 \mathrm{t}$ ha ${ }^{1}+$ bio-fertilizer (Rhizobium + PSB)] during first year and second year, respectively.

Table.1 Physico-chemical properties of the experimental site

\begin{tabular}{|c|c|c|c|c|}
\hline $\begin{array}{l}\text { Sr. } \\
\text { No. }\end{array}$ & Particular & 2014-15 & 2015-16 & Analytical method employed \\
\hline A. & $\begin{array}{l}\text { Mechanical } \\
\text { analysis }\end{array}$ & \multicolumn{2}{|c|}{ Content in soil } & \\
\hline 1. & Sand $(\%)$ & 12.15 & 12.21 & \multirow{3}{*}{$\begin{array}{l}\text { International pipette method (Piper, } \\
\text { 1966) }\end{array}$} \\
\hline 2. & Silt (\%) & 21.45 & 21.25 & \\
\hline 3. & Clay (\%) & 66.40 & 66.55 & \\
\hline 4. & Texture & clayey & clayey & \\
\hline B. & \multicolumn{4}{|l|}{ Chemical analysis } \\
\hline 1. & $\mathrm{pH}_{(2.5)}$ & 8.64 & 8.59 & Potentiometric (Jackson, 1967) \\
\hline 2. & $\mathrm{EC}_{(2.5)}\left(\mathrm{dS} \mathrm{m}^{-1}\right)$ & 1.39 & 1.35 & Conductometric (Jackson, 1967) \\
\hline 3. & Organic carbon $(\%)$ & 0.51 & 0.56 & $\begin{array}{l}\text { Walkley and Black s rapid titration } \\
\text { method (Jackson, 1967) }\end{array}$ \\
\hline 4. & \multicolumn{3}{|c|}{ Exchangeable Cations $\left[\mathrm{cmol}\left(\mathrm{p}^{+}\right) \mathrm{kg}^{-1}\right]$} & \\
\hline I & $\mathrm{Ca}^{+2}+\mathrm{Mg}^{+2}$ & 37.78 & 40.52 & $\begin{array}{l}\text { Complexometric titration } \\
\text { (Jackson, 1967) }\end{array}$ \\
\hline Ii & $\mathrm{Na}^{+}$ & 5.33 & 5.25 & Flame photometric method \\
\hline iii & $\mathrm{K}^{+}$ & 2.45 & 2.54 & (Jackson, 1967) \\
\hline 5. & ESP & 11.70 & 10.87 & \\
\hline
\end{tabular}


Table.2 Effect of land configuration and bio-organic on exchangeable cations and exchangeable sodium percentage in soil after harvest of chickpea

\begin{tabular}{|c|c|c|c|c|c|c|c|c|}
\hline \multirow{3}{*}{ Treatment } & \multicolumn{6}{|c|}{ Exchangeable cations $\left[\mathrm{cmol}\left(\mathrm{p}^{+}\right) / \mathrm{kg}\right]$} & \multirow{2}{*}{\multicolumn{2}{|c|}{$\operatorname{ESP}(\%)$}} \\
\hline & \multicolumn{2}{|c|}{$\mathrm{Ca}^{+2}+\mathrm{Mg}^{+2}$} & \multicolumn{2}{|c|}{$\mathbf{K}^{+}$} & \multicolumn{2}{|c|}{$\mathrm{Na}^{+}$} & & \\
\hline & 2014-15 & $2015-16$ & 2014-15 & 2015-16 & 2014-15 & $2015-16$ & 2014-15 & 2015-16 \\
\hline \multicolumn{9}{|l|}{ (a) Main plot [Land configuration (L)] } \\
\hline $\mathrm{L}_{1}$ : Flat bed & 43.1 & 44.4 & 2.75 & 2.79 & 5.07 & 4.97 & 10.04 & 9.60 \\
\hline $\mathrm{L}_{2}$ : Raised bed & 43.3 & 45.2 & 2.79 & 2.84 & 5.04 & 4.93 & 9.92 & 9.39 \\
\hline $\mathrm{L}_{3}$ : Ridge and furrow & 44.7 & 46.3 & 2.82 & 2.89 & 4.90 & 4.87 & 9.44 & 9.06 \\
\hline S.Em. \pm & 0.71 & 0.63 & 0.04 & 0.03 & 0.07 & 0.06 & 0.17 & 0.12 \\
\hline $\mathrm{CD}(\mathrm{P}=0.05)$ & NS & NS & NS & NS & NS & NS & NS & NS \\
\hline C.V.\% & 6.48 & 5.54 & 5.96 & 4.17 & 5.44 & 4.48 & 6.77 & 5.24 \\
\hline \multicolumn{9}{|l|}{ (b) Sub plot [Bio-organic (B)] } \\
\hline $\begin{array}{l}\mathrm{B}_{1}: \text { No organic fertilizer }+ \text { bio-fertilizer } \\
(\text { Rhizobium }+ \text { PSB })\end{array}$ & 38.9 & 41.2 & 2.56 & 2.64 & 5.10 & 5.18 & 10.98 & 10.58 \\
\hline $\begin{array}{l}\mathrm{B}_{2}: \text { FYM @ } 10 \text { t } \text { ha }^{-1}+\text { bio-fertilizer } \\
\text { (Rhizobium + PSB })\end{array}$ & 48.7 & 49.4 & 2.98 & 3.14 & 4.86 & 4.63 & 8.60 & 8.10 \\
\hline $\begin{array}{l}\mathrm{B}_{3} \text { : Biocompost @ } 5 \mathrm{t} \mathrm{ha}^{-1}+\text { bio-fertilizer } \\
\text { (Rhizobium + PSB) }\end{array}$ & 45.6 & 47.2 & 2.80 & 2.88 & 4.97 & 4.89 & 9.33 & 8.91 \\
\hline $\begin{array}{l}\mathrm{B}_{4} \text { : Vermicompost @ } 2 \mathrm{t} \mathrm{ha}^{-1}+\text { bio-fertilizer } \\
\text { (Rhizobium + PSB) }\end{array}$ & 41.7 & 43.3 & 2.73 & 2.80 & 5.08 & 5.00 & 10.29 & 9.79 \\
\hline S.Em. \pm & 0.59 & 0.63 & 0.04 & 0.03 & 0.06 & 0.05 & 0.13 & 0.11 \\
\hline $\mathrm{CD}(\mathrm{P}=0.05)$ & 1.7 & 1.8 & 0.11 & 0.09 & 0.16 & 0.16 & 0.39 & 0.31 \\
\hline Interaction $(\mathrm{L} \times \mathrm{B})$ & NS & NS & NS & NS & NS & NS & NS & NS \\
\hline C.V.\% & 4.69 & 4.85 & 4.89 & 3.64 & 3.82 & 3.81 & 4.73 & 3.99 \\
\hline
\end{tabular}


Whereas, the lower values of exchangeable $\mathrm{Na}^{+}$were 4.86 and $4.63 \mathrm{cmol}\left(\mathrm{p}^{+}\right) \mathrm{kg}^{-1}$ also noted under treatment $\mathrm{B}_{2}$ during both the years, respectively but, it was remain at par with treatment $\mathrm{B}_{3}$. This might be due to solubilization of native $\mathrm{CaCO}_{3}$ and $\mathrm{MgCO}_{3}$ by the production of organic acids during decomposition of organic matter and also release potassium from FYM resulted in an increase of exchangeable cations. Similar findings were also reported by Deshpande et al., (2015).

It was clear from the data (Table 2) that exchangeable sodium percentage of soil after harvest of chickpea was significantly influenced by different bio-organic treatments during both the years. Among the bio-organic treatments, application of FYM @ $10 \mathrm{t} \mathrm{ha}^{-1}+$ bio-fertilizer (Rhizobium + PSB) $\left(\mathrm{B}_{2}\right)$ recorded significantly the lowest exchangeable sodium percentage of soil after harvest of chickpea which were 8.60 and 8.10 per cent during $1^{\text {st }}$ and $2^{\text {nd }}$ year of study, respectively. Significantly the highest values of exchangeable sodium percentage of soil were recorded under treatment $\mathrm{B}_{1}$ [no organic fertilizer + bio-fertilizer (Rhizobium + PSB) during both the years. The ESP of soil decreased up to 27.67 and 30.62 per cent during 2014-15 and 2015-16, respectively under treatment $\mathrm{B}_{2}$ as compared to treatment $\mathrm{B}_{1}$.

The decrease in ESP may be attributed to higher organic matter which may increased exchangeable cations due to microbial decomposition/humification of organic matter produced organic acid resulted in solubilization of $\mathrm{CaCO}_{3}$ and $\mathrm{MgCO}_{3}$, these cations displacement of $\mathrm{Na}^{+}$ions on exchangeable complex. Higher root proliferation might have been another important cause as the $\mathrm{CO}_{2}$ exhaled by roots result as a formation of carbonic acid. Dubey and Datt (2014) have also reported similar results.

\section{Interaction effect}

Interaction effect due to land configuration and bio-organic did not bring any remarkable variation on exchangeable cations $\left(\mathrm{Ca}^{+2}+\right.$ $\mathrm{Mg}^{+2}, \mathrm{~K}^{+}$and $\mathrm{Na}^{+}$) as well as exchangeable sodium percentage in soil after harvest of chickpea crop during both the years of experimentation (Table 2).

From the present study, it was concluded that sowing of chickpea on ridge and furrow with FYM@10 t ha ${ }^{-1}+$ bio-fertilizer (Rhizobium + PSB) in costal salt affected soils of south Gujarat improves the exchangeable cations like $\mathrm{Ca}^{+2}+\mathrm{Mg}^{+2}$ and $\mathrm{K}^{+}$and reduced the exchangeable $\mathrm{Na}^{+}$and exchangeable sodium percentage in soil.

\section{Acknowledgements}

The authors are grateful to Soil and Water Management Research Unit, Navsari Agricultural University, Navsari for providing financial assistance through NFSM project during the course of investigation.

\section{References}

Deshpande, A.N., Dalavi, S.S., Pandey, S.H., Bhalerao1, V.P. and Gosavi, A.B. 2015. Effect of rock phosphate along with organic manures on soil properties, yield and nutrient uptake by wheat and chickpea. J. Indian Soc. Soil Sci., 63(1): 93-99.

Dubey, Y.P. and Datt, N. 2014. Influence of organic, inorganic and integrated use of nutrients on productivity and quality of pea (Pisum sativum L.) vis-à-vis soil properties. Indian J. Agri. Sci., 84(10): 1195-1200.

IAB. 2000. Indian Agriculture in Brief. (27 $7^{\text {th }}$ edition). Agriculture Statistics Division, Ministry of Agriculture, Govt. of India, New Delhi. 
Jackson, M.L. 1967. Soil Chemical Analysis. Prentice Hall of India Pvt. Ltd., New Delhi. pp. 183-192.

Minhas, P.S., Sharma, O.P and Patil, S.G. 1998. Twenty-five years of research on management of salt affected soils and use of saline water in agriculture. CSSRI publication, Karnal.

Piper, C.S. 1966. Soil and Plant Analysis, Indian Ed. Hans. Pub., Bombay. pp. 223-237.

Rathod, I.R., Ahlawat, R.P.S., Raman, S. and Patel, J.B. 2004. Performance of gatton panic (Panicum maximum Jacq) and ameliorative changes in coastal salt affected soils under varying land configurations. Pak. J. Biol. Sci., 7(3): 350-352.

Velayutham, M. and Bhattacharya, T. 2000. Soil resource management. In natural resource management for agricultural production in India (Yadav, J.S.P. and Singh, G.B. Ed.). Indian Soc. Soil Sci., New Delhi.

Yadav, H.D., Yadav, O.P. Dhankar, O.P. and Oswal, M.C. 1989. Effect of chloride salinity and boron on germination, growth and mineral composition of chickpea (Cicer arietinum L.). Annals Arid Zone J., 28: 63-70.

\section{How to cite this article:}

Vikas Vishnu, V.P. Usadadia, Anil Kumar Mawalia and Patel, M.M. 2017. Effect of Land Configuration and Bio-organic on Exchangeable Cations and Exchangeable Sodium Percentage of Soil after Harvest of Chickpea (Cicer arietinum L.) Under Costal Salt Affected Soils. Int.J.Curr.Microbiol.App.Sci. 6(4): 477-482. doi: https://doi.org/10.20546/ijcmas.2017.604.056 